\title{
GOVERNANCE OF TOURISM IN OECD COUNTRIES
}

\author{
NOEL SCOTT and GIUSEPPE MARZANO
}

\begin{abstract}
This paper discusses trends in tourism governance in OECD countries and identifies good practice. Governance is defined as the exercise of political, economic and administrative authority necessary to manage a nation's affairs. The material for this paper is derived from a review of government websites and publications, a survey of policy material provided to the OECD tourism unit by member countries and discussions with OECD and member country representatives. The paper draws together good practice from around the world and provides an assessment of governance issues from the perspective of national tourist administration organisations. Seven areas of best practice are identified.
\end{abstract}

Keywords: destination management; governance; tourism policy.

NOEL SCOTT is Professor in the Griffith Institute for Tourism, Griffith University, Gold Coast, Australia. Email: noel.scott@griffith.edu.au

GIUSEPPE MARZANO is Dean of Graduate Programs at Universidad de Las Americas, Quito, Ecuador. Email: gmarzano@udla.edu.ec 


\section{Introduction}

Governance within the tourism sector is a challenging task as it involves a variety of stakeholders who are sometimes only weakly aware of what tourism is. Tourism is an 'open' sector of the economy, with low barriers to entry and is subject to the threats and opportunities from numerous political, social, environmental and technological trends (Costa, 2013). Tourism is also considered a fragmented industry meaning that there are few large companies who can provide leadership. Instead provision of tourism services are primarily provided by micro, small and medium size suppliers although some sectors such as aviation are dominated by large businesses operating at a global scale (Dredge, 2006). In an absence of industry leadership, governments at the national and sub-national level often adopt a coordination role for the numerous private sector businesses (of varying scales and sophistication that both compete and co-operate with one another) that operate within a destination (Scott, Cooper, \& Baggio, 2008). However, once governments become involved in tourism, another challenge to effective governance is due to their conflicting priorities. Governments influence the tourism sector in a variety of roles and capacities: border security, regulation of aviation markets; management of tourist attractions such as national parks and beaches; and through funding infrastructure such as roads and convention centres (Burns, 2004). Each of these roles may be controlled by different parts of the government and these may have different priorities leading to conflict or exercise of power. As tourism is often not recognised as a priority area requiring effective policy and governance, in some instances little attention is given within government to its co-ordination.

In some countries though, government involvement in tourism, through various types of regulation, mobilizing and guidance, has a long history, and is also recorded and discussed in the academic literature (Akama, 2002; Choy, 1993; Jenkins, Hall, \& Mkono, 2014; Pastras \& Bramwell, 2013). Arguably, state engagement in tourism is justified since the state is well placed to work for collective interests and to steer the actions of diverse actors, and its actions are relatively open to public scrutiny (Boekholt \& Thuriaux, 1999; Yu, 2000). However, a particular state may not necessarily promote democracy, efficient policymaking, equitable policy outcomes, or effective coordination in destinations. Government involves the formal and informal institutions and practices of the state, and it is organised in a hierarchy from national to regional and local geographical scales. Effective coordination of tourism work by the state depends on it securing cooperation for its actions among different government 
organisations and between the state and actors beyond government. Such coordination can be difficult to achieve in destinations because of the imbalances of resource that characterise how different stakeholders are able to contribute to the decision-making processes (Marzano \& Scott, 2009). As a consequence of its open nature, the tourism industry requires a governance system - a set of rules of the game - that would allow for discretionary behaviour and flexible adaptation to new circumstances, as well as being acceptable for a wide range of different interests (Grandori, 1997).

\section{What is governance?}

How are these rules of the game developed and who develops them? This question is one of the most significant problems in organizational scholarship (O'Mahony \& Ferraro, 2007). In essence, a governance system is the means by which social collectives govern, organize, and coordinate the actions of individuals to achieve collective outcomes. Government and governance, while clearly related, are different concepts (Karns \& Mingst, 2004). The outputs of governance are, in fact, not different from those of government. It is rather a matter of a difference in the processes needed for creating the conditions for ordered rule and collective action (Stoker, 1998). As Rosenau (1992, p. 4) suggests, both government and governance refer to purposive behavior, to goal-oriented activities, to systems of rule; but government suggests activities that are backed by formal authority, by police powers to insure the implementation of duly constituted policies, whereas governance refers to activities backed by shared goals that may or may not derive from legal and formally prescribed responsibilities and that do not necessarily rely on police powers to overcome defiance and attain compliance.

Governance, in other words, is a more encompassing phenomenon than government. It embraces governmental institutions, but it also subsumes informal, nongovernmental mechanisms whereby those persons and organizations within its purview move ahead, satisfy their needs, and fulfill their want. The governance capacity is, in fact, the formal and factual capability of public or private actors to define the content of public goods and to shape the social, economic, and political processes by which these goods are provided (Knill \& Lehmkuhl, 2002, p. 43). 
Shipley and Kovacs (Shipley \& Kovacs, 2008, p. 215) present the definition of the Canadian Institute on Governance as: "governance is a dynamic interaction involving 'structures, functions (responsibilities), processes (practices) and organizational traditions that the board of an organization uses to accomplish the organizing mission". Alongside the concept of governance, some derivations on the concept were also recognized as good governance (Beaumont \& Dredge, 2010; Plummer \& Fennell, 2009; Shipley \& Kovacs, 2008), collaborative governance (Jamal \& Watt, 2011) and governance in the context of regional and local levels (Zahra, 2011). The common underlying feature of governance is concerted interactions between several actors towards social purposes, which aim to be more effective than the state was before in doing the work on its own, lone and authoritative, in past decades (Borges, Eusébio, \& Carvalho, 2014).

By analogy with governance generally, Bramwell and Lane (2011) propose that tourism governance is the processes for producing social order by the regulation and mobilization of social action amongst tourism stakeholders. It is therefore critical to achieve an understanding of how the institutional arrangements for governance of a tourism system are conceptualized in order to determine the ways in which the state acts in the tourism policy arena and therefore selects instruments and indicators that are used to achieve policy goals. Hall (2011) proposes a framework of governance typologies characterised by different relationships between actors and steering modes. Networks and communities are described as nonhierarchical steering modes, the former integrated by public and private actors and the latter by private actors only. Markets represent a hierachical steering mode where private actors are preminent wheras nation state and supranational institutions are hierachies where public actors play a central role. Within this framework, a supra-national organization model of governance - such as the OECD - fits into last category in which governments play a central role in tourism governance.

The literature about tourism governance also takes a normative perspective concerned with the allocation of roles and responsibilities between public entities and private stakeholders (Ruhanen, Scott, Ritchie, \& Tkaczynski, 2010). On one hand, tourism governance could be described in terms of a top down approach where governments or supra national organization forge an ideal public good and provide infrastructure, planning control, marketing and promotion aimed to achieve that which, from the top is perceived to be best for a destination 
(Yuksel, Bramwell, \& Yuksel, 2005). On the other hand, a bottom up approach would prescribe the need for the involvement of local communities in creating a vision and a plan for the development of the destination that may or may not require the support of public organization (Vernon, Essex, Pinder, \& Curry, 2005). From other perspectives, tourism governance has been related to the personal characteristics of the destination stakeholders (Beritelli \& Bieger, 2013), or to the quality and strength of relationships amongst them (Scott et al., 2008; Volgger \& Pechlaner, 2014; von Friedrichs Grängsjö, 2003).

The process by which government coordinates and steers policies and policy activities is also explored and justified under different theoretical perspectives such as the New Institutionalism or the Strategic-Relational Approach (Pastras \& Bramwell, 2013). As Derco (2012) suggests, effective governance requires government and the industry to work together in order to achieve organizational arrangements that foster cooperation based on collaboration and coordination of providers of services together with a system of legal regulations and clear definition of the competencies and responsibilities of individual entities (state, regional and local self-governments, regional and local DMOs), Pechlaner et al (2012) relate destination governance to corporate governance and propose that stakeholder involvement, efficiency, evidence of performance, level of cooperation and the acceptance of the tourism organization are the critical factors that describe good destination governance.

Tourism governance is therefore a complex and multidimensional issue in which the state and other actors depend on each other (Borges et al., 2014). Unless industry and government policy-makers work together effectively, this complex system may not function optimally (Wong, Mistilis, \& Dwyer, 2011). In order to deal effectively with these challenges there is need to strengthen institutional governance mechanisms, so that more effective tourismrelated policies can be developed, and to make changes in the organisation of government institutions to maintain competitive advantage. Thus Frischtak (1994) writes that governance could be defined as the ability to coordinate the aggregation of diverging interests to promote policy, projects, and programs that credibly represent the public interests. Public involvement, institutional development, transparency of decision making procedures, interest representation, conflict resolution, limits of authority, and leadership accountability are all issues of governance. 


\section{OECD definition of governance}

International organizations such as the United Nations or the OECD have their own understanding of governance. The OECD defines governance as the exercise of political, economic and administrative authority necessary to manage a nation's affairs (OECD, 2006a, p. 147). Governance in tourism has been defined as a system and process to define strategies and implement them to achieve competitiveness and sustainable development of the tourism destination (UNWTO, 2011). In its work on public governance, the OECD (2011b, p. 19) has identified the following elements of good governance: accountability, transparency, efficiency and effectiveness, responsiveness, forward-looking vision, and rule of law. Other principles of good governance that may be taken for granted by governments in their normal processes but are of fundamental importance when developing public private partnerships are: legitimacy of the organisation's authority to govern and inclusiveness of the different stakeholders. In addition the nature of tourism policy requires consideration of: a whole of government approach: integration of policymaking at horizontal and vertical levels and the capacity of organisations and individuals to develop and implement policy.

Clearly, tourism governance is complex and while some authors have sought to examine the academic literature of governance (Ruhanen et al., 2010), there are few papers that compare and contrast governance arrangements across different jurisdictions. This paper identifies the main challenges to effective governance and policy development in tourism, and provides examples of good practice in OECD member countries aimed at achieving a 'whole of government' approach. While there is unlikely to be one set of governance arrangements that are universally applicable, the findings of this study may be a source of inspiration and learning for others.

\section{Methodology}

The material for this paper is derived from a review of government websites and publications, and policy material provided to the OECD tourism unit by member countries, a survey of OECD country National Tourist Administrations concerning governance trends and issues. In the survey, central government tourism agency representatives from OECD and selected non-OECD member countries were asked to identify effective enablers of good public governance, examples of policies or practices relating to good tourism governance, and to identify major challenges to effective governance of tourism. This data was analysed to identify emerging trends and examples of good practice for governance of tourism at 
central government and sub-national level, and between government and industry. The analysis procedure involved identification of thematic areas where there appeared to be some trends amongst countries to adopt a particular governance arrangement or to address a particular issue. One of the authors developed an initial series of themes, followed by discussion and validation of these themes with the relevant OECD Tourism Committee country representatives during a face-to-face presentation and through subsequent discussions. A draft of the findings was circulated to representative of member countries and after comments were received, a final report was published as a chapter in "OECD Tourism Trends and Policies 2012” (OECD, 2012b). This paper provides a brief discussion of important themes in three broad areas - horizontal coordination across central government ministries, vertical coordination across central, state and local levels of government and interaction with industry. The results are followed by identification of seven principles of good practice for tourism governance relevant to government.

\section{Thematic findings}

The themes identified as relevant and important by each country varied. Horizontal and vertical tourism policy co-ordination was seen as the greatest or a major challenge to effective tourism governance by counties responding to the survey, followed by financial pressures faced by tourism public agencies, and then external impacts such as economic, safety/security, and natural disasters.

\section{Role of central government}

An important role of central government is developing cohesive, effective tourism policy, but government faces numerous challenges in crafting this policy. This is due in part to the nature of tourism as an 'open', fragmented industry where it is usual to find that multiple central government ministries and levels of government are undertaking various tourism related roles. However, the problems faced by tourism policy makers, due to institutional and territorial fragmentation and difficulties in co-ordination across multiple levels of government, and between government and the private sector, are often similar to those experienced in other areas such as environmental policy.

While in the past a number of governments have noted the contribution that tourism can make to regional economic development and to cultural or social change, there has recently been a positive reassessment of the significance of tourism by many. This is reflected in the gradual rise in status of tourism departments within governments, and in many countries the 
transfer of tourism policy responsibilities to economic and trade related ministries. The development of the Tourism Satellite Account (TSA) in countries such as Australia, Egypt and Canada, to more accurately estimate the economic benefits of tourism, has played an important role in increasing the sector's recognition and profile within government. However, there remains a need for those ministries responsible for tourism to continue to build links and relationships with other areas of central government and establish procedures for dealing with policy issues.

Government at national, regional and local levels are often playing an increasing role in the delivery of tourism. However, a challenge is that in many countries this role has evolved in an ad-hoc manner and often with no clear definition of the overall role of tourism beyond its contribution to economic development. In the past, an increase in the importance of tourism was reflected in additional funding for promotion and marketing. Today, the role of government policy is expanding into areas such as encouraging additional (often low cost) aviation services; developing new niche markets such as health and wellness tourism, ecotourism, meetings and convention travel; increasing the diffusion of ICT among small businesses; examining the impact of tourists on regional sustainability; and dealing with the effects of crises and disasters on the industry. In these areas, the challenge is to link tourism policy to that of other ministries involved in these overlapping policy fields. This policy complexity, along with more recognition of tourism's importance, is leading to a systematic evaluation of the roles of government at various levels, and of industry, in governance arrangements. A recent trend in some countries (including France, Greece, Hungary, Mexico, Slovak Republic, Spain, Cambodia, and Vietnam), is to pass laws that define the roles of organisations involved in tourism policy and planning at various levels of government.

Effective tourism policy requires integration of environmental, social and economic perspectives and hence the need for various ministries and agencies to work together at the central government level. This horizontal policy integration requires the co-ordination of policy across organisations at the same administrative level. Policy integration requires common understandings of the aims and objectives of all parties involved, and some level of agreement on priorities, outcomes and methods, along with the capacity to develop effective, integrated policy solutions. Integration also requires that policies are adopted and applied 
consistently throughout the public administration, and calls for a normative framework, planning, evaluation, oversight and control (OECD, 2011b).

A whole of government approach also requires effective links to regional policies and to government priorities and actions at sub-national level (OECD, 2005). Coherence and consistency are essential in the design and application of policies between all levels of government to ensure that tourism policies are effective. The challenge of vertical policy integration is co-ordination between central, sub-national and local government levels. Further, since tourism is dynamic, governments face the difficulty of constantly monitoring the marketplace to ensure policy is effective.

The role of government in tourism is also continually evolving and in a majority of OECD countries there is an increasing focus on 'supply-side' issues in addition to 'demandside’ marketing and promotion. Examples include Mexico where FONATUR is the central government agency responsible for tourism development and Spain which has established a Programme for the Integral Requalification of Mature Tourism Destinations in four pilot destinations: Beach of Palma in the Balearic Islands; Costa del Sol in Andalusia; San Bartolomé de Tirajana; and Puerto de la Cruz in the Canary Islands. Improvements in the supply-side are focused on enhancing the competitiveness of the tourism industry by increasing productivity and quality, and encouraging innovation (OECD, 2010a, p. 64). There are a number of implications in adopting a 'supply-side' development role. This new role increases the scope and complexity of government policy for tourism and also requires greater development of linkages with government ministries and other organisations, such as government innovation agencies and universities. Effective development of supply-side policies requires a longer-term planning perspective compared to that required for the promotion of existing tourism products. It also requires the development of new organisational competencies for central government tourism organisations and poses questions about how the private sector should be involved, as co-operation is essential to stimulate structural change and innovation in tourism (OECD, 2006b). There appears to be a trend towards the adoption, by governments such as Finland, Portugal and Switzerland, of a role to promote innovation.

\section{A whole of government approach to tourism policy}

Horizontal co-ordination of policy making involves the development of cohesive and integrated policy across ministries and organisations at the same administrative level. 
Tourism policy is influenced to a large extent by, and affects, other policy fields, such as fiscal, environmental, financial, transport, health, labour, social, education and foreign policy. Each of these has its own legal regulations affecting tourism, to a lesser or greater degree. Subsectors of tourism are also regulated by special laws, such as travel contract law or hotel regulations. Horizontal policy co-ordination is important for central government and also is necessary at sub-national level.

Vertical co-ordination involves policy integration between levels of government. One of the reasons why vertical co-ordination is so important is because many governments are decentralising their tourism decision-making, as can be observed in France, Italy, Spain and Brazil. Government at the sub-national level has the advantage of being close to the market, private sector and to citizens and hence is often better placed to identify changing market conditions and developing issues. Decentralisation also allows local government to be in a better position to formulate and implement policies and regulations, which will allow the private sector to operate more effectively. A report by the OECD (2004) identified partnership and decentralisation as two means to improve governance.

In practice, the balance between central and regional control as well as the institutional arrangements and governance structures adopted is also determined by a country's historical development and specific laws and institutions. On the other hand tourism around the world must integrate with common global distribution and transport systems as well as abiding by internationally recognised laws and procedures. As a result there is also a tendency towards similar solutions to common policy and organisational issues. This provides an opportunity for countries to learn from the experiences of others in the area of tourism governance. Mechanisms that support a 'whole of government' approach may be grouped into three broad categories; improved co-ordination, tourism strategies, and use of contracts. These different mechanisms are not independent and are often used together to form multi-level policy networks.

\section{Improved co-ordination}

Examples of improved government co-ordination include: merging government departments, co-ordination forums, specific projects, and working groups (OECD, 2010b, p. 51). Coordination through merging of government departments is evident in a number of OECD countries, and examples of tourism being incorporated into Ministries related to economic affairs or small business, include Canada, Finland, France, Germany, New Zealand, Norway, 
Portugal, and the Slovak Republic. The advantage of this approach to co-ordination is that it facilitates prioritisation of tourism within other economic development activities. A potential disadvantage is that tourism could get 'lost' within a larger department. A second means of co-ordination across government ministries is through the use of task-oriented forums or ongoing committees. Inter-ministerial committees and commissions are a simple and common instrument for co-ordination at a central government level. Three characteristics of these coordinating bodies stand out: 1) formality/informality; 2) political level co-ordination; and 3) links with budget allocation mechanisms. Such co-ordination mechanisms are also used for inter-governmental co-operation.

\section{Tourism strategies}

Another common mechanism for co-ordination across ministries and public agencies is the development of a tourism strategy. Such strategies can play a key role in engaging government, industry, destination communities and other stakeholders in order to identify a vision, direction and goals for tourism development, and in setting priorities for implementing a long-term and sustainable vision for the tourism sector (OECD, 2010a, p. 51). In developing a tourism strategy, a number of important issues need to be clarified, including: the degree of commitment, from relevant agencies and levels of government, to its goals and objectives, and to the specific programmes and measures proposed; responsibility for ensuring the implementation of measures which fall under the purview of non-tourism areas of government; and how the implementation of these measures will be ensured and evaluated (OECD, 2010b, p. 2). In Australia, the development and enhancement of the National Long-Term Tourism Strategy involved horizontal and vertical co-ordination through participation in working groups, as well as regular meetings of all Commonwealth, State and Territory Tourism Ministers, who gather at least once annually to provide direction to reform and implementation of the Strategy.

Countries face a number of problems in the implementation of a national tourism strategy, once developed. One important problem area is the provision of sufficient funding to effectively implement the actions in the strategy. Around half of the respondent countries indicated that funding was a major, or the greatest, problem faced. There are also problems in ensuring the implementation of strategic initiatives by other ministries or agencies. To help with this compliance, and to better inform stakeholders of progress in strategy implementation, increasing attention is being paid to the effective communication of a 
countries' tourism strategy to government, industry and the wider public. The internet is often used as a cost effective means of communicating such strategies.

\section{Contractual arrangements}

Contracts are a governance mechanism commonly used to improve policy implementation (OECD, 2007b). Contractual arrangements across government levels specify the objectives of a particular tourism policy and development programme. The conditions that must be met may be very detailed in terms of lead time, technology content, environmental impact, costs, etc. The contract will usually specify financial transfers that are required for the success of the programme. The conditions that go with these transfers may vary but, as with all types of contract, they shape the incentives influencing the behaviour of local government or other partners. Contracts allow for decentralisation of policy implementation whilst allowing central government to maintain overall coherence and consistency. Contractual arrangements are commonly used in many countries for programmes involving vertical and horizontal relationships. Contracts between central government ministries involved in regional policy are used to overcome the traditional separation of sector policies. Contracts at the sub-national level may involve the participation of different local authorities within a tourism destination as well as the private sector. For example, in Italy, an "agreement for synergic promotion in tourism” was signed between the central Government and Regions in order to strengthen co-operation.

There are problems in using contracts, mainly linked to the nature of the relationship among the partners. Contracts will be more successful if all parties involved are actively engaged in the development of the contract conditions and are supportive of the purposes of the programme. This has led, in some instances, to the introduction of incentives for the different parties to participate fully and to fulfil their contractual obligations. In general contract-based regional development should aim to: ensure that local authorities are empowered; preserve the negotiating power of the central government with respect to other actors; focus contractual arrangements on a limited number of key programmes, while leaving some room for local targeting; and ensure the transparency of the process and open the contractual negotiation to public participation, at least at some stages (OECD, 2007b).

\section{Networks of collaboration}

In practice the mechanisms discussed above may be used simultaneously, with multiple horizontal and vertical links between organisations at different levels of government as well 
as development of collaboration with the private sector. In this situation, particular tools or mechanisms such as contracts and financing between the partners are important elements, but effective co-ordination relies on a number of facilitative conditions for success. Such integrated action across the multiple institutional levels, both public and private, fundamentally relies on the idea of collaboration. Development of collaboration is generally considered to occur through a number of stages such as problem-setting, direction-setting and structuring (Gray, 1985). Co-operation fundamentally relies on the identification and recognition of common interests and interdependence in achieving them. It also requires the involvement of all stakeholders who are perceived to have a legitimate 'stake' in the outcome and a legitimate and skilled convenor who can 'bring the stakeholders together'. Importantly, co-operation requires sharing of power in direction setting and decisionmaking. In the structuring phase, the stakeholders discuss the problem and develop a solution that is consistent with their organisations' requirements. Collaboration, however, is a more intense form of relationship than co-operation and implies a proactive contribution rather than mere compliance.

These networks of collaboration - sometimes termed multi-level governance - therefore require the explicit or implicit sharing of policymaking authority, responsibility, development and implementation at different administrative and territorial levels, for example:

- across different ministries and/or public agencies at central government level (upper horizontally),

- between different layers of government at local, regional, provincial/state, national and supranational levels (vertically), and

- across different actors at sub-national level (lower horizontally) (OECD, 2011b, p. 4).

\section{Tourism governance at sub-national level}

In many countries the full competence for tourism does not lie with the central governments, therefore, there is a significant role to be played in tourism governance at this level. One primary difference is that sub-national governments do not have the main role in many important policy areas such as border control or aviation arrangements. In addition, the central government will often seek to harmonize the tourism policies of the sub-national governments to ensure that the private sector does not face significantly different policy 
regimes in the regions in which it operates. Another important issue for many central governments is the development of a country brand that can provide an 'umbrella' under which the sub-national brands may function. Clearly then governance of tourism at the subnational level must involve consideration of the potential to work under a national umbrella brand, to be effective.

A second important issue is that at the sub-national level there is an opportunity to interact with a wide variety of smaller businesses, and regional or local industry representative bodies. At a central government level, it is often necessary and beneficial to interact with peak industry bodies and the largest tourism businesses, such as airlines, international hotel chains and tour operators. As a consequence, at the sub-national level these interactions tend to be less frequent, except in the largest tourism destinations, and governments must consider how to interact with large numbers of small and diverse private sector businesses.

This closeness to the private sector will often mean that sub-national governments will be responsible for operational regulation and enhancement of service quality. Sub-national governments must also concern themselves with land-use planning as tourism is specific to a particular site or location. One of the consequences is that in many countries, there is a significant history of tourism policy development at the sub-national level and development of a national policy for tourism may be relatively new. In those countries with three levels of government, the differences between central and regional government in policy focus and ‘closeness' to small businesses are replicated between regional and local governments. Sub-national governments often have two organisations for management of tourism. The first is the government ministry or agency that is ultimately responsible for policy and governance issues, provides an interface to other ministries such as those concerning economic development or the environment. The second, a destination management organisation (DMO), often in the form of a public private partnership, manages the interface with the private sector and has a primary responsibility for marketing and promotion. The DMO is usually funded by, and reports to, the responsible sub-national government ministry or agency. A regional DMO may also establish a series of sub-regional or local DMOs to provide a destination level structure.

Tourism has a number of characteristics that lead to the formation of destinations and ensure they are key organisational units for policy and planning. The tourism sector is composed of a relatively small number of large companies (airlines, hotel chains, tour companies) that 
compete globally, and a vast majority of small businesses that operate primarily in one destination. These small business operators have little independent influence and therefore they often join industry or sectorial organisations to represent their interests, in addition to joining local organisations concerned with local geographic issues. Large global companies have substantial market power but need to co-ordinate with governments for access and with smaller companies in specific destinations for their day to day operations.

Effective governance at the sub-national level, with or without a DMO in place, is strongly connected with active participation by the stakeholders. In economic development, there is now a consensus that action must be co-ordinated at the local level, and ideally also with related policy areas, to stimulate synergy, avoid conflicts, and make the best possible use of the information available. Improving local governance i.e., the way policies are co-ordinated, adapted to local conditions and oriented in partnership with civil society and business (OECD, 2001, p. 13), has thus itself become a goal of government. Improving local governance enhances the effectiveness of certain policies and takes full advantage of the resources and energy of business, civil society and the other levels of government in the pursuit of common objectives (OECD, 2004, p. 10).

\section{Tools for capacity-building}

One of the most important challenges of vertical and horizontal co-operation mechanisms is to enhance the competence of local actors (OECD, 2005, p. 16). Good policy design is not sufficient to achieve desired outcomes. Implementation plays a critical role in making a reform successful or hindering its scope. Implementation capacity refers to the mechanisms used by reformers to shape and influence strategy/policy implementation and to influence the behaviour of other stakeholders in the organisational network. It recognises the importance of skills and resources (e.g. financial, material, human, knowledge, and even time) within the organisation and their utilisation by policy actors. Building human capacity at the national and sub-national levels involves education and training, and participation in learning-bydoing programmes such as those involved in 'learning region’ initiatives.

Tourism learning regions aim to strengthen the performance of various tourism stakeholders - especially but not exclusively small-medium tourism enterprises (SMTEs) - via the creation of networks of learning. Traditionally, SMTEs do not engage in formal learning, offer few training opportunities to their staff and do not engage easily with public agencies (OECD, 2012a). The rationale for setting up learning regions is that issues such as quality, 
ICT, skills, marketing and customer focus, and other business practices are placed firmly on the agenda of SMTEs by encouraging reflection on good practice.

One of the key aspects of learning regions is that they make training more accessible to SMTEs by seeking to build provision in partnership with them and around their 'world' rather than in the 'world of the trainers'. One of the key benefits is that this is more likely to yield a higher rate of participation than traditional approaches to developing skills and encouraging learning. The approach requires strong partnership arrangements, a sense of moving forward for all key partners, and resources to develop key features of the learning region. As a result, the support of a 'champion' is often instrumental to success and this implies a degree of capability building with potential champions prior to trying to establish a learning region (OECD, 2007a).

Education and training is a continuing issue for tourism capacity building (OECD, 2012a), and plays an important role in tourism governance through enhanced understanding of policy issues and of management skills needed for a collaborative environment. In a recent review of tourism policy in Italy, it was recommended that there should be enhanced transfer of knowledge from the education sector to the industry, for example through a tourism intelligence network (OECD, 2011a, p. 113). There should be an integrated governmental approach, closely associating the regions, the private sector and the education and training organisations. This approach should support skills diversity and attractive careers in tourism. It further suggested that Italy should also develop a map of tourism professions and their skills, to identify the future needs and the skills gaps in tourism education and training. A number of skills development and training resources are available from the OECD, as well as other international organisations, and universities. Exchange programs, and peer networks, for example, of city managers, may be developed to play a role in capacity building initiatives. Pro-active interaction between local leadership and larger enterprises may also be instrumental in helping the transformation of conservative city-regions into more proactive entrepreneurial innovation systems (OECD, 2008, p. 100), as can networks and the development of learning regions (OECD, 2008, p. 101). These initiatives encourage inter-firm and inter-sectorial linkages that can provide collective efficiencies and learning effects within the regional economy.

Tools for capacity-building available at the national and sub-national levels include basic principles of capacity development (OECD, 2006b, p. 133), stakeholder analysis (OECD, 
2006, p. 33), and resident attitude surveys (Andriotis, 2002). At a municipal or regional level, capacity-building should seek to map the supply of skills with demand, and fill identified gaps accordingly. Capacity building activities can focus on a range of issues including the promotion of positive cultures; constructive communication and engaged communities; transparency and accountability; vision and leadership; acceptance of diversity and the pursuit of equity and inclusiveness; developing knowledge learning and sharing expertise; clear roles and responsibilities of participants; and clear operational structures and processes of the network.

Effective tourism governance across multiple levels of government requires competent actors at the national and sub-national levels. Tools for capacity building include mapping of human resource capacity and skills training, often provided by the national government and by international organisations such as the OECD. However, it is important to tailor training to deliver the specific skills required. Capacity building of tourism operators and local governments may be enhanced by active 'learn-by-doing’ programmes and the development of learning regions.

\section{Tourism governance: co-ordination and interface with industry}

Increasingly, central, regional and local governments are seeking private sector involvement in policy development as well as developing collaborative partnerships with the private sector and tourism supplier associations to co-operatively develop marketing plans, identify tourism development opportunities and provide input into policy and tourism strategies. This involvement may include direct engagement with larger businesses or representative industry bodies in order to capture the diverse views of numerous small businesses, which is notoriously difficult to achieve in a traditionally fragmented and geographically extensive sector dominated by SMEs.

One of the problems in seeking industry level policy input is that there are usually a number of industry bodies that represent different types of businesses such as tour companies, hotels, attractions, tour guides, and so on. Because each of these groups of businesses have particular issues and problems it is difficult for tourism to 'speak with one voice', and there are several ways industry can respond:

- An industry branch approach where hotels, travel agents etc. have bodies to represent themselves individually. 
- A more integrated approach, where peak tourism industry bodies (at the national or international level) are established to more effectively speak on behalf of tourism as a whole. Examples include Exceltur, the US Travel Association, and the World Travel and Tourism Council (WTTC). These bodies may also have representation at subnational level.

- A mixed approach.

Branch versus integrated approach to organisation of industry representative bodies

An industry branch approach allows the particular policy issues of the various tourism sectors to be represented. For example, hotels may have issues that should be addressed in developing a policy on reduction of smoking while these may not be relevant in the aviation sector where smoking is banned. In addition, it provides a mechanism for government to encourage and address particular types of tourism businesses such as ecotourism, adventure tourism, and so on. However, the proliferation of industry branches can mean that a private sector business may be expected to join a number of associations at a substantial cost.

At a national level, there is a trend towards an integrated approach, creating one peak industry representative body, which may be comprised of organisations representing different sectors. One advantage of this approach is that it removes government from negotiation with multiple organisations and transfers responsibility for developing a single private sector policy position to the peak body. Dealing with a peak industry body provides a means for government to address both general policy issues and those relating to specific industry branches, and can facilitate a more rapid response in situations where an urgent response is required. On the other hand such peak bodies can tend to represent the interests of larger private sector businesses or other groups leading to problems of their representativeness.

A mixed approach, where there is a peak tourism body representing a significant section of the industry (integrated approach), but also a limited number of industry branches representing their own interests (industry branch approach), is likely to be the most common situation. This approach may require the government to identify the appropriate organisation/s or businesses with whom to co-ordinate in relation to specific policy issues. An alternative approach is to request industry input on policy issues from all representative 
organisations, with the degree of input received determined by the perceived importance of the policy issue for each organisation. This may be likened to a market approach.

\section{Conclusion}

Based on the thematic findings detailed in this paper, and responses to a survey of OECD country members, the following have been identified as examples of good practice in the governance of tourism and, as such, important considerations in any policy response to improve the supporting framework for effective tourism governance.

1. A clear definition of the roles of various levels of government in tourism as well as definition of the roles and functions of the various organisations involved in tourism policy is an area of good practice. In some countries such as Vietnam and Cambodia, these roles are being specified in law.

2. At a national level, there is a trend to development of one peak industry association which may be a conjugate representative body comprised of organisations representing different sectors. However, the approach taken in particular countries appears to vary significantly and a dominant approach is yet to emerge. At a sub-national level, a variety of different organisations may be found in a particular destination, representing particular sectors or branches of national representative organisations. While there is agreement that sub-national coordination amongst these organisations is good practice, the appropriate means by which it is obtained appears to be context dependent.

3. A tourism strategy is a commonly used tool for engaging and co-ordinating government, industry, destination communities and other stakeholders. Development of an effective tourism strategy appears good practice. A common problem with a tourism strategy is the need to provide sufficient funding for its implementation. Communication is an important element of successful implementation of a strategy.

4. Tourism policy governance across multiple levels of government requires competent local actors. A variety of tools for capacity building at the national and sub-national level and include skills training provided by the national government and by international organisations such as the OECD but it is important to tailor training to deliver the skills required. Involvement and capacity building of tourism operators and local government may be enhanced by active 'learn-by-doing' programmes. Development of human capacity at national and sub-national level appears good practice. 
5. DMOs are an important component of effective governance at the subnational level. Their boundaries should reflect both economies of scale in marketing and organisation and be based on the travel patterns of travellers. DMOs also provide a sub-national focus for policy development and capacity building and a focus for communication with private sector stakeholders. Implementation of a sub-national management structures such as DMOs appears good practice for larger countries with larger tourist visitor volumes.

6. In developing policy and responses to crises it is good practice for governments to include tourism representatives in decisions due to the horizontal characteristics of the tourism sector.

7. It is good practice to ensure that relevant data and analysis are available to support tourism policy decisions which in turn may require additional resources and competencies in tourism organisations. It is good practice to ensure that policy decision-making is longerterm, transparent and that outcomes are evaluated.

These best practice findings may be useful for consideration by government organizations at different levels and with varying degrees on interaction with the tourism sector. However there is a continuing need to review and contrast the effectiveness of governance arrangements in different jurisdictions to continue to improve best practice. While reviews of academic papers are useful (see for example: (Borges et al., 2014; Ruhanen et al., 2010)), there is also need to examine real world practice in a comparative manner. This has been the approach of this paper. While there have been a plethora of studies that examine individual contexts and situations, comparative studies are rare although see Almeida García (2014) and (Derco, 2012). It may also be useful to examine the contribution of individuals and their interest and passion in governance (Gardiner \& Scott, 2014). Such studies will advance academic knowledge as well as having direct application for government.

\section{Acknowledgements}

This article builds on the work of the OECD Tourism Committee to facilitate an integrated governmental approach to tourism development. 


\section{References}

Akama, J. (2002). The role of government in the development of tourism in Kenya. International Journal of Tourism Research, 4, 1-13.

Almeida García, F. (2014). A comparative study of the evolution of tourism policy in Spain and Portugal. Tourism Management Perspectives, 11, 34-50.

Andriotis, K. (2002). Residents' satisfaction or dissatisfaction with public sector governance: The Cretan case. Tourism \& Hospitality Research, 4(1), 53-68.

Beaumont, N., \& Dredge, D. (2010). Local tourism governance: a comparison of three network approaches. Journal of Sustainable Tourism, 18(1), 1-22.

Beritelli, P., \& Bieger, T. (2013). From destination governance to destination leadership-defining and exploring the significance with the help of a systemic perspective. Tourism Review, 69(1), 38.

Boekholt, P., \& Thuriaux, B. (1999). Public policies to facilitate clusters: background, rationale and policy practices in international perspective Boosting innovation: the cluster approach (pp. 381-412). Paris: OECD Publishing.

Borges, M. d. R., Eusébio, C., \& Carvalho, N. (2014). Governance for sustainable tourism: A review and directions for future research. European Journal of Tourism Research, 7, 45-56.

Bramwell, B. (2011). Governance, the state and sustainable tourism: a political economy approach. Journal of Sustainable Tourism, 19(4), 459 - 477.

Burns, P. (2004). Tourism planning: A third way? Annals of Tourism Research, 31(1), 24-43.

Choy, D. J. L. (1993). Alternative roles of national tourism organizations. Tourism Management, 14(5), 357-365.

Costa, C., Panyik, E., \& Buhalis, D. (2013). Trends in European Tourism Planning and Organisation. Bristol, UK: Channel View Publications.

Derco, J. (2012). Destination Governance in the Czech Republic, Slovakia and Poland. Tourism Planning \& Development, 10(3), 354-364. doi: 10.1080/21568316.2012.747987

Dredge, D. (2006). Policy networks and the local organisation of tourism. Tourism Management, 27(2), 269-280.

Frischtak, L. L. (1994). Governance capacity and economic reform in developing countries (Vol. 254): World Bank Publications.

Gardiner, S., \& Scott, N. (2014). Successful Tourism Clusters: Passion in Paradise. Annals of Tourism Research, 46, 171-173.

Grandori, A. (1997). Governance structures, coordination mechanisms and cognitive models. Journal of Management \& Governance, 1(1), 29-47.

Gray, B. (1985). Conditions Facilitating Interorganizational Collaboration. Human Relations, 38(10), 911-936.

Hall, C. M. (2011). A typology of governance and its implications for tourism policy analysis. Journal of Sustainable Tourism.

Jamal, T., \& Watt, E. M. (2011). Climate change pedagogy and performative action: toward community-based destination governance. Journal of Sustainable Tourism, 19(4), 571 - 588.

Jenkins, J. M., Hall, C. M., \& Mkono, M. (2014). Tourism and public policy. In A. A. Lew, C. M. Hall \& A. M. Williams (Eds.), The Wiley Blackwell Companion to Tourism (pp. 542-555): Wiley-Blackwell.

Karns, M. P., \& Mingst, K. A. (2004). International organizations: the politics and processes of global governance. London: Lynne Rienner Publishers.

Knill, C., \& Lehmkuhl, D. (2002). Private actors and the state: Internationalization and changing patterns of governance. Governance, 15(1), 41-63. 
Marzano, G., \& Scott, N. (2009). Power in destination branding. Annals of Tourism Research, 36(2), 247-267.

O'Mahony, S., \& Ferraro, F. (2007). The emergence of governance in an open source community. Academy of Management Journal, 50(5), 1079-1106.

OECD. (2001). Local Partnerships for Better Governance. Paris: OECD.

OECD. (2004). New Forms of Governance for Economic Development. Paris: OECD.

OECD. (2005). Building Competitive Regions: Strategy and Governance. Paris: OECD Publishing.

OECD. (2006a). Applying Strategic Environmental Assessment: Good Practice Guidance for Development Co-operation: OECD Publishing.

OECD. (2006b). Innovation and Growth in Tourism. Paris: OECD.

OECD. (2007a). Fostering SME and Entrepreneurship Development in the Tourism Sector in Bulgaria - An active review: OECD.

OECD. (2007b). Linking Regions and Central Governments: Contracts for Regional Development. Paris: OECD Publishing.

OECD. (2008). Strategies for Urban Competitiveness and Governance: The Case of Cape Town: GOV/TDPC/URB(2008)1. Paris: OECD.

OECD. (2010a). Metropolitan governance: a goal in search of a model OECD Territorial Reviews: Venice, Italy 2010: OECD Publishing.

OECD. (2010b). OECD Tourism Trends and Policies 2010: OECD.

OECD. (2011a). Italy Tourism Policy Reveiw: OECD.

OECD. (2011b). Towards More Effective and Dynamic Public Management in Mexico OECD Public Governance Reviews: OECD Publishing.

OECD. (2012a). OECD Tourism Trends and Policies 2012. Paris: OECD.

OECD. (2012b). Tourism governance in OECD countries. In OECD (Ed.), OECD Tourism Trends and Policies 2012. Paris: OECD.

Pastras, P., \& Bramwell, B. (2013). A strategic-relational approach to tourism policy. Annals of Tourism Research, 43, 390-414.

Pechlaner, H., Volgger, M., \& Herntrei, M. (2012). Destination management organizations as interface between destination governance and corporate governance. Anatolia, 23(2), 151168.

Plummer, R., \& Fennell, D. A. (2009). Managing protected areas for sustainable tourism: prospects for adaptive co-management. Journal of Sustainable Tourism, 17(2), 149-168.

Rosenau, J. N. (1992). Governance without government: order and change in world politics. In J. N. Rosenau \& E.-O. Czempiel (Eds.), Governance Without Government: Order and Change in World Politics (pp. 1-29): Cambridge Univ Press.

Ruhanen, L., Scott, N., Ritchie, B., \& Tkaczynski, A. (2010). Governance: A Review and Synthesis of the Literature. Tourism Review, 65(4), 4-16.

Scott, N., Cooper, C., \& Baggio, R. (2008). Destination Networks: Four Australian Cases. Annals of Tourism Research, 35(1), 169-188.

Shipley, R., \& Kovacs, J. F. (2008). Good governance principles for the cultural heritage sector: lessons from international experience. Corporate Governance, 8(2), 214-228.

Stoker, G. (1998). Governance as theory: five propositions. International Social Science Journal, 50(155), 17-28.

UNWTO. (2011). Governance for Sustainable Tourism Development. Algarve, Portugal: Universidade do Algarve/UNWTO.

Vernon, J., Essex, S., Pinder, D., \& Curry, K. (2005). Collaborative policymaking: local sustainable projects. Annals of Tourism Research, 32(2), 325-345.

Volgger, M., \& Pechlaner, H. (2014). Requirements for destination management organizations in destination governance: Understanding DMO success. Tourism Management, 41(0), 64-75. doi: http://dx.doi.org/10.1016/j.tourman.2013.09.001

von Friedrichs Grängsjö, Y. (2003). Destination networking: Co-opetition in peripheral surroundings. International Journal of Physical Distribution \& Logistics Management, 33(5), 427-448. 
Wong, E. P. Y., Mistilis, N., \& Dwyer, L. (2011). A framework for analyzing intergovernmental collaboration - The case of ASEAN tourism. Tourism Management, 32(2), 367-376. doi: DOI: $10.1016 /$ j.tourman.2010.03.006

Yu, T. F.-L. (2000). A new perspective on the role of the government in economic development: coordination under uncertainty. International Journal of Social Economics, 27(7/8/9/10), 9941013.

Yuksel, F., Bramwell, B., \& Yuksel, A. (2005). Centralized and decentralized tourism governance in Turkey. Annals of Tourism Research, 32(4), 859-886.

Zahra, A. L. (2011). Rethinking regional tourism governance: the principle of subsidiarity. Journal of Sustainable Tourism, 19(4), 535 - 552. 